\title{
Próby modelowania dynamiki narzędziowej wczesnych hominidów w świetle archeologii kognitywnej
}

Ważne dla filozofii wnioski - w obszarze problematyki genealogii człowieka - bywają formułowane bez dostatecznej weryfikacji danych empirycznych oraz w oparciu o pewne aprioryczne przeświadczenia. W ostatnich kilku dekadach, wraz z przyrostem danych empirycznych, rozgorzała debata dotycząca charakterystyki najwcześniejszej kamiennej technologii i jej wkładu w interpretację dotyczaca pochodzenia ludzkiej kultury. Pod dyskusję poddano kwestie związane z naturą wczesnych wytworów olduwajskich oraz wynikających z nich implikacji dla zrozumienia poznawczych zdolności pierwszych wytwórców narzędzi kamiennych ${ }^{1}$.

1 Zob. T. Wynn, The Intelligence of Later Acheulean Hominids, „Man” 14 (1979), s. 371-91; T. Wynn, The Intelligence of Oldowan Hominids, ,Journal of Human Evolution” 10 (1981), s. 529-541; T. Wynn, W. C. McGrew, An Ape's View of the Oldowan, „Man” 24 (1989), s. 383-398; K. D. Schick, N. Toth, Making Silent Stones Speak: Human Evolution and the Dawn of Technology, New York 1993; Tools, Language, and Cognition in Human Evolution, ed. K. Gibson, T. Ingold, Cambridge 1993; S. Semaw, The World's Oldest Stone Artifacts from Gona, Ethiopia: Their Implications for Understanding Stone Technology and Patterns of Human Evolution between 2.62.5 Million Years ago, „Journal of Archaeological Science” 27 (2000), s. 1197-1214; H. Roche, From Simple Flaking to Shaping: Stone-knapping Evolution Among Early Hominids, w: Stone Knapping, the Necessary Conditions for a Uniquely Hominin Behavior, ed. V. Roux, B. Bril, Cambridge 2005; J. Pelegrin, Remarks about Archaeological Techniques and Methods of Knapping: Elements of a Cognitive Approach 
W sukurs trwającym dyskusjom dotyczącym poziomu poznawczych zdolności naszych praprzodków miała przyjść archeologia kognitywna. Termin ,archeologia kognitywna” został na stałe wprowadzony do naukowej nomenklatury na początku lat osiemdziesiątych ubiegłego wieku w odniesieniu do studiów dawnych społeczności, w których wyraźnie zwracano uwagę na procesy ludzkiego myślenia i zachowania symbolicznego. Archeologia kognitywna to interdyscyplinarny obszar badań, w ramach których zastosowanie maja teorie i metody kilku akademickich dyscyplin, takich jak: archeologia, paleoantropologia, psychologia poznawcza, neuropsychologia, filozofia umysłu, neuroanatomia i inne. Stawiane pytania głównie dotyczą pochodzenia i adaptacyjnej roli takich poznawczych procesów i zdolności jak: tworzenie pojęć, poznanie przestrzenne, poznanie społeczne, język, symboliczne struktury i pamięć robocza. Wszystko to zmierza do określenia rozwoju poznawczych umiejętności u ludzi oraz naszych antenatów w świetle psychologii, antropologii i oczywiście filozofii ${ }^{2}$.

Celem niniejszego artykułu nie jest analiza osiagnięć wielopłaszczyznowej i dynamicznie rozwijającej się dyscypliny, jaka jest archeologia kognitywna ${ }^{3}$, a jedynie próba wykorzystania tych jej elementów, które moga pomóc w rekonstrukcji poznawczej dynamiki hominidów, leżącej u podstaw umiejętności wytwarzania i używania jednych z najstarszych narzędzi kamiennych. Próbując określić, co składa się na ową dynamikę kognitywna, należy wpierw spróbować znaleźć pewne różnorodne, ale powiązane ze sobą działania selektywne. Jeżeli możemy ustalić, że jakieś kamienie były:

to Stone Knapping, w: Stone Knapping, the Necessary Conditions for a Uniquely Hominin Behavior, ed. V. Roux, B. Bril, Cambridge 2005.

2 Por. np. T. Wynn, The Intelligence..., dz. cyt.; J. Gowlett, Mental Abilities of Early Man: a Look at Some Hard Evidence, w: Hominid Evolution and Community Ecology, ed. R. Foley, London 1984; S. P. McPherron, Perspectives on Stone Tools and Cognition in the Early Paleolithic Record, w: Tool Use in Animals. Cognition and Ecology, ed. C. M. Sanz, J. Call, Ch. Boesch, Cambridge 2013.

3 Por. np. C. Renfrew, E. B. W. Zubrow, The Ancient Mind, Cambridge 1994; S. Mithen, The Prehistory of Mind, London 1996; Cognitive Archaeology and Human Evolution, ed. S. De Beaune, F. L. Coolidge, T. Wynn, Cambridge 2009; Stone Tools and the Evolution of Human Cognition, ed. A. Nowell, I. Davidson, Boulder 2010. 
selekcjonowane z punktu widzenia właściwości wewnętrznych, selekcjonowane z punktu widzenia lokalizacji, selektywnie obrabiane z punktu widzenia kształtu, selektywnie obrabiane z punktu widzenia rozmiarów, a ta selektywność była skorelowana i podporządkowana pewnej proceduralnej całości, a więc zintegrowana - to możemy przyjać, że jest to wyraz wielu różnorodnych działań, które coś łączy ${ }^{4}$. Tym, co zdaje się łączyć te różnorodne działania, może być pewna stała poznawcza dyspozycja, która zdaje się mieć oparcie w procesach poznawczych, zaangażowania zaawansowanych form planowania, rozwiązywania problemów, kontroli poznawczej i rozumowania przestrzennego.

W tym właśnie kontekście bardzo istotne jest całościowe ujęcie behawioru narzędziowego hominidów. Rozpoznawanie złożonych procesów poznawczych związanych z działalnością hominidów jest sprzeczne z redukcjonistyczną metodą dowolnej fragmentaryzacji materiału empirycznego. Redukcja pola widzenia lub redukcja aspektów obserwacji może i musi uniemożliwiać rozpoznanie poznawczej charakterystyki typowej dla działalności praprzodków człowieka. Innymi słowy, analiza procesów poznawczych stojących za danym wytworem materialnym wymaga podporządkowania procesu badawczego całościowości przedmiotu poznania. Nie można zapominać, że cały proces produkcji narzędzi kamiennych podporządkowany jest funkcjom, które mają one pełnić, a te sa konsekwencją behawioru konkretnego osobnika. Wytwarzanie narzędzi kamiennych należy więc rozpatrywać w kontekście późniejszego ich użycia. Tylko całościowe, holistyczne ujęcie wytwarzania i używania narzędzi może nam dać wgląd w pełen repertuar poznawczych kompetencji hominidów. Sposobności do tego typu analiz dostarcza jeden z najstarszych zespołów narzędzi kamiennych i artefaktów zaliczanych do przemysłu olduwajskiego, odkrytych w Kenii na stanowisku Lokalalei i datowanych na około $2,3 \mathrm{mln}$ lat temu.

Poczynione ustalenia mogą mieć duże znaczenie w argumentacji filozoficznej w ramach sporów o genealogię człowieka i mogą stanowić

4 Por. P. Lenartowicz, Zjawisko biologiczne a pojęcie racjonalności (spór o geneze pojęć teleologicznych), „Ruch Filozoficzny” 53 (1996) nr 2-3, s. 197-207. 
przesłankę do przyjęcia tezy o zaawansowanych zdolnościach poznawczych wczesnych hominidów, żyjących już około $2,3 \mathrm{mln}$ lat temu ${ }^{5}$.

\section{Próby oceny poznawczych zdolności hominidów w oparciu o archeologię kognitywną}

Najstarsze narzędzia kamienne - od momentu, kiedy stały się przedmiotem naukowej refleksji - prowokowały do dyskusji w kwestii poznawczych kompetencji ich wytwórców. To głównie z końcowych produktów litycznej obróbki próbowano wywnioskować, które elementy motywacji, intencjonalności oraz decyzji musiały być obecne w trakcie czynności narzędziotwórczych.
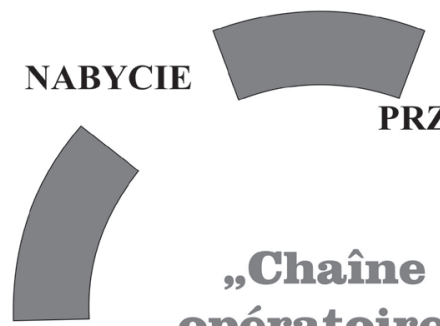

PRZYGOTOWANIE

PORZUCENIE

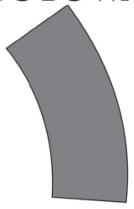

opératoire"

REDUKCJA

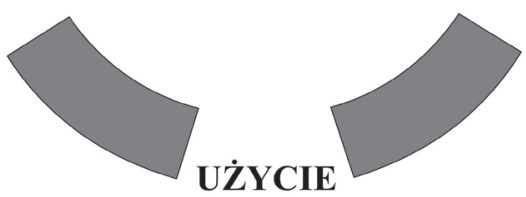

Ryc. 1. Ogniwa łańcucha czynności (fr. chaîne opératoire).

5 W tym miejscu należy wspomnieć o niedawnym odkryciu najstarszych (obecnie znanych) narzędzi kamiennych, datowanych na 3,3 mln lat temu i pochodzących ze stanowiska Lomekwi 3 w Kenii. Zob. S. Harmand et al., 3.3-million-year-old Stone Tools from Lomekwi 3, West Turkana, Kenya, „Nature” 521 (2015).

6 Zob. A. F. Pawlik, Is the Functional..., dz. cyt., s. 3 (zmodyfikowane). 
W latach osiemdziesiątych ubiegłego wieku zaczęto stosować holistyczne podejście do technologicznej analizy sekwencji redukcji materiału litycznego; określono je jako chaîne opératoire ${ }^{7}$, co można przetłumaczyć na język polski jako „ogniwa łańcucha czynności”. Sekwencje ogniw łańcucha czynności obejmuja: techniki i strategie pozyskiwania surowego materiału, przygotowania rdzenia, redukcji i modyfikacji, użycia oraz ostatecznie porzucenia ${ }^{8}$ (zob. Ryc. 1).

Archeologia kognitywna zwraca szczególną uwagę na operacyjne procesy związane z lityczną obróbka, a mniej skupia się na gotowej formie. Sekwencja działań nakierowanych na uzyskanie zamierzonego końcowego produktu zazwyczaj rozpoczynała się od początkowej selekcji materiału skalnego, następnie przygotowania otoczaka do obróbki, wyboru odpowiedniego tłuczka, oddzielenia odłupków - które w późniejszym czasie mogły być przerobione na narzędzia lub stanowiły odpad - i ukształtowania ostatecznej formy rdzenia. Analiza ogniw łańcucha czynności opiera się na swoistym „odczytaniu” kierunków i kolejności odbijanych odłupków, zmierzających do uzyskania finalnej formy narzędzia. Idealną metodą rekonstrukcji sekwencji działań jest ponowne złożenie, dopasowanie odłupków do rdzenia, z którego zostały odbite, tak aby stanowiły pierwotna formę. Nie jest to łatwe, a często wręcz niemożliwe, gdy czas „zerwał” łączność sekwencji działań i nie jest ona widoczna w zapisie archeologicznym. Wiadomo również, że hominidy przenosiły zarówno materiał skalny, jak i gotowe narzędzia po terenie, na którym przebywały, co przekłada się na fakt rozproszenia w czasie i przestrzeni pozostałych fragmentów.

Szczątkowość i fragmentaryczność danych empirycznych dodatkowo utrudniaja próby ustalenia poznawczego potencjału naszych antenatów. Trudności w interpretacji potęguje dość powszechny redukcjonizm badawczy koncentrujący się bądź to tylko na gotowych produktach, bądź to wyłącznie na ich funkcjach lub też na samym

7 Por. np. J. M. Geneste, Analyse Lithique d'Industries Moustériennes du Périgord: Une Approche Technologique du Comportement des Groupes Humains au Paléolithique Moyen, Bordeaux 1985.

8 Por. A. F. Pawlik, Is the Functional Approach Helpful to Overcome the Typology Dilemma of Lithic Archaeology in Southeast Asia?, „IPPA Bulletin” 29 (2009), s. 3. 
procesie obróbki narzędzia. Tylko holistyczne ujęcie zagadnienia, obejmujące cały cykl chaîne opératoire, daje nam podstawę do prób poprawnego wnioskowania. Brak całościowego ujęcia może prowadzić do nieporozumień; i tak dla jednych poszczególne typy narzędzi moga być robiacymi wrażenie przykładami planowania ${ }^{9}$, a dla innych uzyskanymi przypadkowo odpadami ${ }^{10}$.

Majac na uwadze powyższe trudności, omawiany w niniejszym artykule zespół narzędziowy pochodzący ze stanowisk Lokalalei 1 (GaJh5) i Lokalalei 2C (LA2C), położonych na zachód od Jeziora Turkana, datowanych na około $2,34 \mathrm{mln}$ lat temu, ze względu na fakt, że znacząca jego część może być ponownie złożona i dopasowana - ukazując proces litycznej redukcji - stanowi jeden z najważniejszych punktów odniesienia dla oceny poznawczych zdolności wczesnych człowiekowatych ${ }^{11}$.

\section{Próba rekonstrukcji ogniw lańcucha czynności działalności narzędziowej hominidów - przykład z Lokalalei}

Odkryty przez francuską misję archeologiczną (kierowaną przez Hélène Roche) zespół narzędzi kamiennych ze stanowiska Lokalalei 2C (LA2C) ukazuje udokumentowany na miejscu pełny cykl produkcji zarówno jednostronnych, jak i dwustronnych narzędzi otoczkowych ${ }^{12}$.

9 Zob. np. J. Gowlett, Mental Abilities..., dz. cyt.

10 Zob. np. Human Evolution, Language and Mind: a Psychological and Archaeological Inquiry, ed. W. Noble, I. Davidson, Cambridge 1996.

11 Zob. H. Roche, Technological Evolution in Early Hominids, „OSSA: International Journal of Skeletal Research” 14 (1989), s. 97-98; H. Roche, Remarque sur les plus anciennes industries en Afrique et en Europe, w: Colloquium VIII: Lithic Industries, Language and Social Behaviour in the First Human Forms, Forli: IUPSS Congress, (1996), s. 55-68; M. Kibunjia et. al., Pliocene and Pleistocene Archeological Sites West of Lake Turkana, Kenya, „Journal of Human Evolution” 23 (1992), s. 431-438; M. Kibunjia, Pliocene Archaeological Occurrences in the Lake Turkana Basin, „Journal of Human Evolution” 27 (1994), s. 159-171.

12 Zob. J. K. Kozłowski, Świat przed „rewolucja” neolityczna, Kraków 2004, s. 139 (Wielka historia świata, 1). 
Przeprowadzone przez Roche badania ${ }^{13}$ wskazują na wyjątkowość tego znaleziska.

Zestaw lityczny z LA2C jest zdominowany przez produkty debitażu (91 proc.). Te elementy, połączone z rdzeniami i kamiennymi tłuczkami, wskazuja, że na tym stanowisku można zaobserwować ogniwa łańcucha czynności (chaîne opératoire) litycznej produkcji. Reszta zbioru zawiera używane i nieużywane otoczaki. Surowiec skalny, głównie lawa (bazalt i fonolit), był zbierany z okresowych strumieni osuszających Murua Rith, który graniczy od zachodu z Jeziorem Turkana. Zostało zidentyfikowanych dziesięć różnych kategorii surowca skalnego, prawdopodobnie odzwierciedlających różnorodność surowca dostępnego w strumieniach ${ }^{14}$.

\subsection{Selekcja surowca skalnego}

Stanowiska Lokalalei 1 (GaJh5) i Lokalalei 2C (LA2C) ukazuja selekcje surowca skalnego przez zamieszkujące w odległej przeszłości ten teren hominidy ${ }^{15}$. Jak już wspomniano, surowiec skalny, głównie lawa, bazalt i fonolit, był zbierany z efemerycznych strumieni spływających z pasma gór Murua Rith, które od zachodu granicza $\mathrm{z}$ basenem Jeziora Turkana ${ }^{16}$. W rejonie LA2C zidentyfikowano dzie-

13 Zob. H. Roche et. al., Early Hominid Stone Tool Production and Technical Skill 2.34 Myr ago in West Turkana, Kenya, „Nature” 399 (1999), s. 57-60; H. Roche, Stone Knapping Evolution among Early Hominids, Pont-Á-Mousson 2001 (International Workshop, 21-24 November 2001, Abbaye des Prémontrés); H. Roche, From Simple Flaking..., dz. cyt.; H. Roche, A. Delagnes, Evidence of Controlled and Reasoned Stone Knapping at. 2.3 Myr, West Turkana (Kenya), Pont-Á-Mousson 2001 (International Workshop 21-24 November 2001, Abbaye des Prémontrés).

14 Jeśli nie zaznaczono inaczej, tłum. własne. „The lithic assemblage from LA2C is dominated by debitage products (91\%). These elements, associated with the cores and hammerstones, indicate that complete sequences (chaîne opératoire) of lithic production have taken place at the site. The rest of the assemblage consists of worked and unworked cobbles.The raw materials, mainly lavas (basalt and phonolite), were gathered from the ephemeral streams draining the Murua Rith range, which borders the Turkana basin on the west. Ten different categories have been identified, probably reflecting the diversity of raw materials available in the streams" $-\mathrm{H}$. Roche et. al., Early Hominid..., dz. cyt., s. 59.

15 Zob. H. Roche et. al., Early Hominid..., dz. cyt.

16 Zob. H. Roche et. al., Early Hominid..., dz. cyt. 
sięć różnych typów surowca skalnego, który mógłby być potencjalnie użyty do produkcji narzędzi kamiennych, ale to bazalt i fonolit były tymi surowcami, których używano do produkcji artefaktów z LA2C ${ }^{17}$. Roche zwróciła uwagę na fakt, że gruboziarnisty surowiec skalny nie był tak intensywnie eksploatowany, jak ten drobnoziarnisty.

Jak zauważa Sonia Harmand ${ }^{18}$, w obu stanowiskach Lokalalei zachowanie hominidów związane z zaopatrzeniem w surowce ukazuje głęboka starożytność strategii podejmowania decyzji związanych z selekcją surowca skalnego ze względu na jego właściwości łupania i trwałość wytworzonych ostrych, tnących krawędzi oraz unikanie surowca gorszej jakości. Powyższe wskazuje na pewien określony poziom wiedzy i antycypację efektów związanych z jakością surowca skalnego.

Harmand tak pisze na temat umiejętności narzędziotwórczych hominidów sprzed 2,3 mln lat:

Badania związku pomiędzy surowcem skalnym obecnym na stanowiskach archeologicznych a surowcem skalnym występującym w miejscu jego pozyskiwania uwydatnia wysoki poziom planowania i przewidywania już 2,3 mln lat temu. Świadczy to o starannym doborze dobrej jakości skał z naturalnie użytecznymi podstawami uderzeń, w celu prowadzenia długiego procesu obróbki, zgodnie z poziomem umiejętności opanowanym przez wytwórców z Lokalalei $2 \mathrm{C}^{19}$.

17 Por. S. Semaw, The Oldest Stone Artifacts from Gona (2.6-2.5 Ma), Afar, Ethiopia: Implications for Understanding the Earliest Stages of Stone Knapping, w: The Origins of Human Technology: Studies into the Early Stone Age (Oldowan), ed. N. Toth, K. Schick, Bloomington 2006, s. 48.

18 Zob. S. Harmand, Variability in Raw Material Selectivity at the Late Pliocene Sites of Lokalalei, West Turkana, Kenya, w: Interdisciplinary Approaches to the Oldowan, ed. E. Hovers, D. R. Braun, Amsterdam 2009, s. 94.

19 "The study of the relationship between raw materials at sites and raw materials at sources highlights a high degree of planning and foresight as early as 2.34 Ma. This is testified to by the careful selection of good quality rocks with naturally serviceable striking platforms, for the purpose of carrying out long reduction processes according to the level of skill the Lokalalei 2C knappers have mastered" - S. Harmand, Economic Behaviors and Cognitive Capacities of Early Hominins between 2.34 Ma and 0.70 Ma in West Turkana, Kenya, „Mitteilungen der Gesellschaft für Urgeschichte" 16 (2007), s. 16. 
Harmand ${ }^{20}$ na podstawie przeprowadzonych przez siebie badań selektywności różnorodnego materiału skalanego z Lokalalei twierdzi, że harmonizuje ono z nowymi i nieoczekiwanymi rezultatami uzyskanymi we wczesnych olduwajskich lokalizacjach, takich jak Gona i Hadar w Etiopii czy Kanjera w Kenii ${ }^{21}$. Przeczy to powszechnemu przekonaniu, że hominidy z okresu plio-plejstocenu oportunistycznie zbierały surowiec skalny.

Zróżnicowana selekcja i posługiwanie się surowcami skalnymi na późnoplioceńskim stanowisku Lokalalei $2 \mathrm{C}$ sugeruje wrażliwość na jakość surowego materiału skalnego i empiryczną wiedzę na temat mechaniki struktury skał już 2,3 mln lat temu i później ${ }^{22}$.

David Braun i jego współpracownicy ${ }^{23}$, badając dostępność surowca skalnego, jego selekcję i transport w Kanjerze Południowej (Kanjera South), stwierdzili, że hominidy wybierały do transportu okre-

20 Zob. S. Harmand, Raw Materials and Economic Behaviour of Late Pliocene Hominids: the Case of Lokalalei 2 C and Lokalalei 1 Sites, West Turkana (Kenya) (poster presented at the Paleoanthropology Society Annual Meeting, Montreal (Canada), March 30-31, 2004); S. Harmand, Economic Behaviors..., dz. cyt.; S. Harmand, Variability in Raw..., dz. cyt.

${ }_{21}$ Zob. T. W. Plummer, L. C. Bishop, P. Ditchfield, J. Hicks, Research on Late Pliocene Oldowan Sites at Kanjera South, Kenya, „Journal of Human Evolution” 36 (1999), s. 151-170; S. Semaw, The World's Oldest..., dz. cyt.; S. Semaw et al., 2.6-million-year-old Stone Tools and Associated Bones from OGS-6 and OGS-7, Gona, Afar, Ethiopia, „Journal of Human Evolution” 45 (2003), s. 169-177; T. Plummer, Flaked Stones and Old Bones: Biological and Cultural Evolution at the Dawn of Technology, „Yearbook of Physical Anthropology” 47 (2004), s. 118-164; D. Stout, The Social and Cultural Context of Stone-Knapping Skill Acquisition, w: Stone Knapping: The Necessary Conditions for Uniquely Hominin Behaviour, ed. V. Roux, B. Bril, Cambridge 2005; T. Goldman-Neuman, E. Hovers, Methodological Issues in the Study of Oldowan Raw Material Selectivity: Insights from A.L. 894 (Hadar, Ethiopia), w: Interdisciplinary Approaches to the Oldowan, ed. E. Hovers, D. R. Braun, Dordrecht 2009.

22 „The differential selection and management of raw materials at the Late Pliocene site of Lokalalei $2 \mathrm{C}$ suggests sensitivity to the quality of raw materials and an empirical knowledge of the mechanics of rock fracture from 2.3 myrs onwards" S. Harmand, Variability in Raw..., dz. cyt., s. 10.

${ }_{23}$ Zob. D. Braun, M. Rogers, J. Harris, S. Walker, Landscape Scale Variation in Hominin Tool Use: Evidence from the Developed Oldowan, „Journal of Human Evolution" 55 (2008), s. 1053-1063. 
ślony surowiec skalny z częstotliwościa, która jest znacząco różna od skali jego dostępności. Znaczy to tyle, że pewne surowce skalne były transportowane do Kanjery Południowej w większych proporcjach, niż można by tego oczekiwać, opierając się na ich obecności w zbiorowiskach skalnych. Część surowca skalanego została przetransportowana z relatywnie dużej odległości, większej niż 10 km.

Prawie jedna trzecia (27,9 proc.) całego zbioru artefaktów pochodziła z surowców skalnych, które były dostępne tylko w konglomeratach naniesionych przez wodny system rzeki Awash. Selektywny transport był głównym czynnikiem kształtującym zawartość archeologicznej kolekcji (...) hominidy w dorzeczu Winam w okresie pliocenu wykazywały selektywne zachowanie związane z transportem, które wskazuje na wydatkowanie dużej ilości energii na produkcję i utrzymanie zestawu narzędzi kamiennych (...). Te dane empiryczne wspierają coraz częstszą interpretację, że kiedy transport i łupanie kamieni rozpatrzy się wystarczająco szczegółowo, wtedy można dopuścić myśl, że olduwajskie zachowanie narzędziowe było bardziej złożone, niż poprzednio oczekiwano ${ }^{24}$.

Sposób, w jaki radzono sobie z transportem surowca skalnego, również wskazuje na antycypację celu. Małe i średnie otoczaki były zabierane do miejsca obróbki w jednym kawałku, większe były rozłupywane, zanim zostały przetransportowane.

Dodatkowo jeśli porówna się rozmiar, wagę i rodzaj surowca skalnego tłuczków oraz niezmodyfikowanych otoczaków, okazuje się, że kamienne tłuczki są większe niż nieużywane otoczaki (manuporty), a ich rozmiar jest bardziej jednolity. Co ważniejsze, odmienność śred-

24 „Almost one-third (27.9\%) of the entire artifact collection derives from raw materials that were only available in conglomerates deposited by the Awach River system. Selective transport was a major factor shaping the composition of the archaeological collection (...) hominins in the Winam basin during the Pliocene exhibited a range of selective transport behaviors that indicate the expenditure of extensive amounts of energy to produce and maintain a stone tool kit. These data support a growing interpretation that, when transport and stone flaking are considered in considerable detail, Oldowan tool behavior was possibly more complex than previously expected" - D. Braun, M. Rogers, J. Harris, S. Walker, Landscape Scale..., dz. cyt., s. 2343 . 
niej wagi obu kategorii przedmiotów jasno pokazuje, że kamienne tłuczki są cięższe. Nie może to być wprost wytłumaczone poprzez różnice w rodzaju surowca skalnego, ponieważ średnioziarnisty trachit jest dominujacym materiałem skalnym zarówno dla kamiennych tłuczków, jak i nieużywanych otoczaków. Powyższe twierdzenie może świadczyć o tym, że po przetransportowaniu otoczaków i bloków skalnych hominidy wybierały okazy lepiej odpowiadajace do użycia ich jako tłuczków ${ }^{25}$.

Jak pisze Roche, analiza artefaktów z LC2:

(...) prowadzi do generalnej konkluzji, że to działanie wykracza poza proste stereotypowe powtarzanie elementarnych gestów łupania (...). Innymi słowy, wytwórcy narzędzi z Lokalalei $2 \mathrm{C}$ wykazują wyższy poziom technologiczny niż dotychczas udokumentowane umiejętności dla stanowisk z tego samego okresu ${ }^{26}$.

\subsection{Selekcja kształtu i wybór odpowiedniej techniki}

W Lokalalei 2C znaleziono ponad dwa tysiące sześćset artefaktów, w skład których wchodzą całe i uszkodzone odłupki, obrabiane i nieobrabiane otoczaki oraz kamienne tłuczki. Niewielka powierzchnia wykopaliska i doskonały stan, w jakim się znajdowały artefakty, pozwoliły na dopasowanie fragmentów i rekonstrukcję znalezionych oddzielnie, a stanowiących całość, kolejno oddzielanych w procesie wytwarzania narzędzi kamiennych fragmentów. Zrekonstruowano pięćdziesiąt dziewięć grup, co stanowi ponad 10 proc. całego kamiennego inwentarza Lokalalei 2C. Kilka grup, które udało się zrekonstruować, składało się z od dziesięciu do trzydziestu dzie-

25 Zob. A. Delagnes, H. Roche, Late Pliocene Hominid Knapping Skills: The Case of Lokalalei 2C, West Turkana, Kenya, „Journal of Human Evolution” 48 (2005), s. 462 .

26 „The analysis of the organized debitage thus lead to the general conclusion that it goes beyond the simple stereotyped repetition of elementary knapping gestures that characterize other assemblages, and already evinces a certain degree of planning (...). In other words, the Lokalalei $2 \mathrm{C}$ knappers show a higher level of technological skill than documented so far for sites of the same period" - H. Roche, From Simple Flaking..., dz. cyt., s. 40. 
więciu kamiennych fragmentów, co pozwoliło zrekonstruować pracę wytwórców ${ }^{27}$.

Dla 13 najważniejszych grup, które ponownie dopasowano, średnio przypada 18 odłupków na rdzeń, minimalna liczba odłupków to 9 . W jednym wypadku można wykazać, że ponad 30 odłupków było odbitych z 2 fragmentów przynależących do tego samego otoczaka; w innym 50 odłupków było odbitych z tego samego całego otoczaka; w trzecim przypadku, skupiającym 3 niezależnie łupane fragmenty pochodzące $\mathrm{z}$ tego samego otoczaka, wyprodukowano ponad 73 odłupków z tego otoczaka. Jak dotąd nie ma przykładu tego typu wysokiej liczby odłupków wyprodukowanych z pojedynczego kawałka surowca w całym późnym pliocenie lub nawet we wczesnym plejstocenie ${ }^{28}$.

Należy zwrócić uwagę, że całość cyklu produkcji odłupków nie mogłaby być zademonstrowana bez analizy i możliwości dopasowania poszczególnych fragmentów. Przeprowadzona rekonstrukcja i analiza elementów stanowiących kolejne etapy wytwarzania narzędzi kamiennych wskazuje, że ich wytwórcy rozumieli wymogi, które stawia podstawa uderzeń. Zaobserwowano również inne kluczowe elementy świadczące o precyzyjnym behawiorze narzędziowym hominidów:

1. Konkrecje (o odpowiednich morfologicznych właściwościach) były wybierane spośród dostępnego w otaczającym środowisku surowca skalanego lub poprzez rozłupywanie otoczaków, co pozwalało uzyskać pożądany kształt do obróbki.

2. Obróbka surowca skalnego ograniczała się tylko do tych części podstawy uderzeń, która nadawała się do użycia.

27 Por. H. Roche, From Simple Flaking..., dz. cyt., s. 38.

28 „For the 13 most important refitting groups, the average is 18 flakes per core, with a minimum number of 9 flakes. In one case, it could be shown that over 30 flakes were knapped from 2 fragments belonging to the same cobble; in another, 50 flakes were knapped from the same whole cobble; in a third example, concerning 3 independently-knapped fragments originating from the same cobble, production amounts to over 73 flakes for this cobble. So far, there is no example of such a high number of flakes being produced from a single chunk of raw material in the entire Late Pliocene, or even Early Pleistocene, record" - H. Roche, From Simple Flaking..., dz. cyt., s. 38. 
3. Nie sa widoczne nieudane próby uderzeń na obszarze, który uniemożliwiałby odbicie odłupków. W niektórych przypadkach, gdy pewne defekty surowca powodowały utrudnienia $\mathrm{w}$ procesie łupania, podstawa uderzeń była naprawiana.

4. Utrzymywano odpowiedni kształt rdzenia, który zapewniał maksymalne jego wykorzystanie. Aby utrzymać płaską powierzchnię (tę, z której odbija się odłupki), stosowano serię kilku krótkich zbieżnych lub równoległych odbić, które przechodziły przez część łupanej powierzchni. Te odbicia były prowadzone od różnych krawędzi rdzenia, w celu jak najlepszego zrównania płaszczyzny ${ }^{29}$.

Wysoki stopień kontroli nad sekwencją uderzeń wskazuje na zdolność do przewidywania i zrozumienia naprawczej funkcji oddzielonych fragmentów i rezultatu tych serii odbić, utrzymujacych powierzchnię, z której odbija się odłupki, płaską ${ }^{30}$.

W Lokalalei $2 \mathrm{C}$ znaleziono osiemnaście kamiennych tłuczków świadczących o wysokim stopniu zręczności ich użytkowników. Chociaż tłuczki te przedstawiają szeroki wachlarz morfologiczny, noszą one dobrze widoczne obszary uderzeń (czasami dwa lub trzy), świadczące o ich użyciu według powtarzających się i precyzyjnie kontrolowanych sposobów posługiwania się. Słaba kontrola nad kamiennym tłuczkiem widoczna byłaby w szeregu przypadkowych i chaotycznie rozmieszczonych miejsc uderzeń.

Roche $^{31}$ uważa, iż artefakty z Lokalalei $2 \mathrm{C}$ dostarczają pierwszych empirycznych dowodów, że hominidy, które je produkowały, monitorowały obrabiany rdzeń. $\mathrm{W}$ odniesieniu do tego twierdzenia również Jacques Pelegrin ${ }^{32}$ utrzymuje, że podstawa kilku rdzeni była

29 Zob. H. Roche, From Simple Flaking..., dz. cyt., s. 39.

30 Znaleziony i poddany analizie fenolitowy rdzeń (długi na 10,1 cm) z Lokalalei 2C pokazuje stałe i konsekwentne oddzielanie odłupków dokoła jednej powierzchni otoczaka. Aby otrzymać platformę do dalszej obróbki, otoczak wpierw został rozbity wzdłużnie, następnie przez dopasowanie odłupków do rdzenia zrekonstruowano serię ośmiu odbić. Najprawdopodobniej wytwórca odwrócił rdzeń, aby użyć wszystkich dostępnych naturalnych płaszczyzn, i zdaje się, że jasno rozumiał potrzebę utrzymania odpowiedniego kąta płaszczyny. Zob. A. Delagnes, H. Roche, Late Pliocene..., dz. cyt.

31 Zob. H. Roche et. al., Early Hominid..., dz. cyt.; H. Roche, From Simple Flaking..., dz. cyt.

${ }_{32}$ Zob. J. Pelegrin, Remarks about Archaeological..., dz. cyt., s. 27. 
naprawiana przez oddzielenie małych fragmentów skalnych w kierunku aktualnego odbijania odłupków.

Jak pisze na ten temat Pelegrin:

Postrzegam to jako ważny poznawczy wskaźnik: wytwórca nie tylko mógł stwierdzić, że było coś niewłaściwego z istniejącą podstawa, ale czasem mógł również przerwać regularny proces łupania, aby skorygować podstawę uderzeń poprzez odbicie odpowiedniego odłupka - ale oczywiście było to odbicie, które nie wynikało z tego samego porządku łupania, co regularnie produkowane odłupki. Dlatego wytwórca zademonstrował zdolność do: 1) oceny na podstawie istniejącego stanu rzeczy zarówno orientacji, jak i regularności podstawy uderzeń; i 2) modyfikacji w miarę potrzeb, zamiast po prostu zaprzestania działań, kiedy sytuacja (rdzeń) była już nieodpowiednia. Innymi słowy, wytwórca był zdolny na poziomie podjęcia decyzji do zoptymalizowania obecnego stanu rdzenia. Ponadto na żadnym z rdzeni z Lokalalei $2 \mathrm{C}$ nie widać przypadkowego „tłuczenia” ${ }^{33}$.

Narzędzia kamienne z Lokalalei 2C zawierają wyraźne ślady ciężkiej obróbki i liczne ślady precyzyjnej naprawy. Archeolodzy określają sposób wykonania tych narzędzi jako „wyrafinowany”. Natomiast znalezione w tym samym horyzoncie stratygraficznym artefakty ze stanowiska Lokalalei 1 (GaJh5), oddalonego od Lokalalei $2 \mathrm{C}$ o około $1 \mathrm{~km}$, określa się jako wykonane „mniej starannie”.

33 „I see this as an important cognitive indicator: not only could the knapper ascertain that there was something wrong with the existing platform, but s/he also occasionally interrupted the regular knapping process to correct the platform by striking off an appropriate flake - but one which was obviously not of the same order as regular flake products. Thus, the knapper demonstrated the ability: 1) to evaluate on an ongoing basis both the orientation and regularity of the platform; and 2) to modify it as needed, instead of simply stopping when the situation (core) was no longer adequate. In other words, the knapper was capable of a degree of decision making that could optimize the actual condition of the core. Moreover, there is no haphazard "hammering» on any of the Lokalelei 2C cores" - J. Pelegrin, Remarks about Archaeological..., dz. cyt., s. 27.

${ }_{34}$ Zob. M. Kibunjia, Pliocene Archaeological..., dz. cyt.; H. Roche et. al., Early Hominid..., dz. cyt. 
Powodem użycia takiego określenia jest, jak pisze Mzalendo Kibunjia, fakt, iż „około 80 proc. negatywów odbić na tych rdzeniach (sic) charakteryzowało się schodkowatym przełamem [step fracture] i zaobserwowano tylko kilka przykładów całkowicie oddzielonych odłupków”35.

Pomimo tego że w pobliżu znajdowały się źródła różnego rodzaju materiału skalnego, hominidy preferowały surowiec skalny w postaci bazaltu i fonolitu, a w przypadku Lokalalei 1 była to lawa. Archeologów zastanawia niezwykła różnica pomiędzy Lokalalei 1 a Lokalalei 2C. Pomimo tak niewielkiej odległości, która dzieliła oba stanowiska (znajdujące się w tym samym horyzoncie stratygraficznym), różnica w jakości wykonanych narzędzi oraz sposobie eksploatacji materiału skalnego jest zastanawiajacca ${ }^{36}$. Kwestia ta wymaga dalszych badań.

W Lokalalei 2C widoczna jest kontrola obrabianego dobrej jakości surowca skalnego, zgodnie z określonymi, niezmiennymi zasadami. Bloki skalne i otoczaki były dobierane pod względem pewnej szczególnej własności - posiadały naturalną graniastą morfologię, która bezpośrednio dostarczała użytecznej podstawy uderzeń $\left(<90^{\circ}\right)$. Zdarzało się, że płaska powierzchnia była uzyskiwana poprzez rozbicie okragłego otoczaka lub też była uformowana na wewnętrznej stronie dużego odłupka.

Ta płaska powierzchnia była wykorzystywana jako podstawa uderzeń, jako miejsce sukcesywnego i wielokierunkowego seryjnego odbijania równoległych odłupków. Dzięki tym zabiegom utrzymywano płaską podstawę uderzeń, co powodowało, że można było produkować dużą liczbę odłupków.

Ta bardzo specyficzna sekwencja obróbki i wynikająca z tego wysoka wydajność została udokumentowana przez dynamiczną rekonstrukcję całych otoczaków na podstawie informacji z ponownego zrekonstruowania

35 „About $80 \%$ of the flaking scars on these cores (sic) characterized by step fractures and only a few instances of complete flake removals were observed" - M. Kibunjia, Pliocene Archaeological..., dz. cyt., s. 165.

36 Por. S. Semaw, The World's Oldest..., dz. cyt. 
zestawu (gdzie 12 proc. z wszystkich 2,614 artefaktów można dopasować jeden do drugiego). Średnio 18 odłupków było łupanych z każdego rdzenia i do 73 odłupków zostało oddzielonych z pojedynczego bloku surowca. Produkcja tak dużej liczby odłupków pokazuje planowanie i zdolność przewidywania, podczas gdy cała sekwencja działań jest w toku. Ta poznawcza zdolność jest połaczona razem motorycznymi umiejętnościami, widocznymi poprzez wysoką kontrolę ruchów uderzeniowych, które można dostrzec na śladach odłupków i rdzeni, i z bardzo uwydatnionymi i ograniczonymi do jednego miejsca śladami uderzeń na kamiennym tłuczku7 ${ }^{37}$.

Powyższe działania - takie jak chociażby pozyskiwanie i obróbka odpowiedniego surowca, przewidywanie skutków swoich działań czy oburęczna precyzja - wskazują na fakt, że już najstarsze działania narzędziotwórcze wymagały umiejętności, które z łatwością dostrzeżemy w zabiegach narzędziotwórczych z wcześniejszego okresu dziejów ludzkości.

\subsection{Najstarsze ślady używania narzędzi}

Należy zapytać: do jakich celów używano pierwszych wyprodukowanych narzędzi kamiennych? Dwie najpewniejsze odpowiedzi to: do produkcji innych narzędzi kamiennych i do pozyskiwania pokarmu. Czy narzędzia olduwajskie były używane do innych celów? Zanim podejmie się próbę odpowiedzi na to pytanie, należy pamiętać, że używanie narzędzi olduwajskich zakłada jedne z najbardziej problematycznych i oparte na przypuszczeniach aspekty technologii narzędzi kamiennych w skrajnie ograniczonym zapisie archeologicznym.

${ }^{37}$ „This very specific reduction sequence, and the ensuing high productivity have been documented by dynamic reconstruction of entire cobbles on the basis of particularly informative refitting sets (where $12 \%$ of a total of 2,614 artifacts may refit to one another). On average, 18 flakes were knapped from each core, and up to 73 flakes were removed from a single block of raw material. The production of such a large number of flakes shows foresight and anticipation while the whole operational sequence is in progress. This cognitive ability goes with a controlled motor skill, show by the high control of percussion gestures, which can be seen on flakes and cores, and with a very circumscribed and limited area bearing percussion marks on the hammerstones" - A. Delagnes, H. Roche, Late Pliocene..., dz. cyt., s. 439. 
Wytworzenie narzędzi kamiennych nie było celem samym w sobie. Złota zasada inżynierii (w tym ergonomii) zakłada, że to forma podąża za funkcją. Funkcje paleolitycznych narzędzi kamiennych i ich znaczenie przystosowawcze to zagadnienie, z którym zmagają się badacze prehistorii od ponad stu pięćdziesięciu lat. Chociaż pewne analogie oparte na danych etnograficznych rzuciły światło na możliwe zastosowanie narzędzi kamiennych, to nadal jasna identyfikacja funkcji narzędzi paleolitycznych stanowi wyzwanie. Eksperymentalne studia mogą przynajmniej pomóc zidentyfikować pewne funkcjonalne możliwości różnych klas artefaktów (opierając się na kryteriach takich jak kształt, ostrość krawędzi, waga, materiał skalny itd.). Tego typu możliwości mogą się zawierać w wytwarzaniu narzędzi, pozyskiwaniu mięsa, łupaniu orzechów, obrabianiu drewna, kopaniu i wytwarzaniu prostych pojemników. Eksperymenty z użyciem szerokiej gamy narzędzi olduwajskich pokazały szczególne możliwości ostrych odłupków, które do niedawna bywały niedoceniane i traktowano je raczej jako pozostałości po wytwarzaniu narzędzi rdzeniowych ${ }^{38}$. Okazuje się jednak, że odłupki mogą reprezentować centralny komponent olduwajskiego zestawu narzędziowego. Eksperymenty pokazały również związek pomiędzy procesami, np. oddzielaniem mięsa od skóry, ćwiartowaniem, oddzielaniem tuszy, a śladami na narzędziach kamiennych, które mogą być widoczne w prehistorycznym zapisie ${ }^{39}$. Ślady uderzeń na kamiennych otoczakach, subsferoidach lub sferoidach, sugeruja, że obiekty te służyły zasadniczo jako tłuczki do obróbki materiału skalnego i jako takie wprost wskazują na fakt, że człowiekowate używały narzędzi do wytwarzania innych narzędzi. Ślady na kamieniach powstawały, gdy były one używane jako tłuczki. Należy pamiętać, że trudno zidentyfikować ślady użycia kamieni, jeśli były one użyte niewiele razy.

38 Zob. N. Toth, The Stone Technologies of Early Hominids at Koobi Fora, Kenya: an Experimental Approach, Berkeley 1982; N. Toth, The Oldowan Reassessed: a Close Look at Early Stone Artifacts, „Journal of Archaeological Science” 12 (1985), s. 101-120; N. Toth, Behavioral Inferences from Early Stone Artifact Assemblages: an Experimental Model, ,Journal of Human Evolution” 16 (1987), s. 763-787.

39 Por. np. K. D. Schick, N. Toth, Making Silent..., dz. cyt. 
Bardzo wymownym śladem wskazującym na funkcję narzędzi są nacięcia na zwierzęcych kościach znalezionych na olduwajskich stanowiskach archeologicznych. Wskazują one na to, że wczesne hominidy cięły zwierzęce skóry, a także rozczłonkowywały i oddzielały mięso od kości małych, średnich i dużych ssaków. Większość śladów nacięć ukształtowanych jest w zespoły równoległych rowków, co sugeruje, że odłupki o ostrych krawędziach, w przeciwieństwie do jednostronnych lub dwustronnych retuszowanych ostrzy, były głównie artefaktami używanymi jako noże rzeźnicze ${ }^{40}$. Należy mieć jednak na uwadze, że narzędzia rdzeniowe, odłupki i retuszowane narzędzia odłupkowe - wszystkie one dobrze nadają się do oprawiania mięsa, co też potwierdziły eksperymenty ${ }^{41}$. Jest wiele dowodów na to, że długie kości zwierząt były rozłamywane przy pomocy kamiennych tłuków i prawdopodobnie z zastosowaniem kamiennych kowadeł.

Do niedawna najstarsze świadectwa wytwarzania narzędzi kamiennych pochodziły z Gona w Etiopii i były datowane pomiędzy 2,6 a 2,5 mln lat temu ${ }^{42}$. Najnowsze odkrycia archeologiczne na stanowisku Lomekwi 3, znajdującym się na zachodnim brzegu Jeziora Turkana, cofnęły ewidencję wytwarzania narzędzi kamiennych o około 700 tys. lat, do okresu 3,3 mln lat temu ${ }^{43}$. W lokalizacji Bouri kilka kości noszących ślady nacięć dowodzi, że hominidy używały narzędzi kamiennych około 2,5 mln lat temu. Blisko Gona i Bouri znajduje się Dikiki (Etiopia), gdzie na stanowisku DIK-55 odnaleziono kości ze śla-

40 Por. N. Toth, The Oldowan Reassessed..., dz. cyt., s. 112.

${ }_{41}$ Zob. P. R. Jones, Experimental Butchery with Modem Stone Tools and Its Relevance for Paleolithic Archaeology, „World Archaeology” 12 (1980), s. 153-165; P. R. Jones, Results of Experimental Work in Relation to the Stone Industries of Olduvai Gorge, w: Excavations in Beds III, IV and the Masek Beds. Olduvai Gorge, vol. 5, ed. M. Leaky, D. Roe, Cambridge 1994; N. Toth, Behavioral Inferences..., dz. cyt.; N. Toth, The Artefact Assemblages in the Light of Experimental Studies, w: Koobi Fora Research Project. Plio-Pleistocene Archaeology, ed. G. L. Isaac, Oxford 1997.

${ }^{42}$ Por. np. K. D. Schick, N. Toth, An Overview of the Oldowan Industrial Complex: The Sites and the Nature of Their Evidence, w: The Oldowan: Case Studies into the Earliest Stone Age, ed. N. Toth, K. Schick, Gosport 2006; S. Semaw et al., 2.5-million-year-old Stone Tools from Gona, Ethiopia, „Nature” 385 (1997), s. 333-336; S. Semaw, The World's Oldest..., dz. cyt.; S. Semaw et al., 2.6-million-year-old..., dz. cyt.

${ }_{43}$ Zob. S. Harmand et al., 3.3-million-year-old..., dz. cyt. 
dami nacięć wykonanych kamiennych narzędziami ${ }^{44}$. Badania mikroskopem potwierdziły, że kości noszą ślady nacięć wykonane narzędziami kamiennymi i powstałymi najprawdopodobniej podczas odcinania mięsa. Dopatrzono się również śladów uderzeń wynikłych z prób pozyskania szpiku kostnego. Datowanie znaleziska wskazuje na to, że kości te sa starsze niż 3,39 mln lat. Przywołane badania archeologiczne wskazują na fakt, że narzędzia kamienne były wytwarzane i używane około 700 tys. lat wcześniej, niż do tej pory sądzono, i związane z tym zachowanie narzędziowe może być przypisane już australopitekom.

\section{Podsumowanie}

Natura wczesnych olduwajskich stanowisk może być wyznacznikiem implikacji do zrozumienia poznawczych zdolności wczesnych wytwórców narzędzi kamiennych. Obecne dane archeologiczne są wystarczające, aby móc opisać proces wytwarzania narzędzi kamiennych od selekcji surowego materiału skalnego, transportu, produkcji, do użycia i porzucenia.

Dla kognitywnego podejścia do zapisu archeologicznego analiza ogniw łańcucha czynności jest interesująca i atrakcyjna, ponieważ wypływa bezpośrednio z teoretycznej perspektywy, która łączy działania ze świadomymi decyzjami i zamiarami w umyśle wytwór$c y^{45}$. W tej perspektywie szczególnie istotne sa momenty, kiedy kilka różnych (alternatywnych) działań jest możliwych, a podjęte działanie reprezentuje intencjonalny wybór dokonany przez wytwórcę.

Wraz z rosnaccą liczbą coraz starszych znalezisk suponowano, iż pogłębiać się będzie prowizoryczność oraz doraźność działalności

${ }_{44}$ Zob. S. P. McPherron et. al., Evidence for Stone-Tool-Assisted Consumption of Animal Tissues before 3.39 Million Years ago at Dikika, Ethiopia, „Nature” 466 (2010), s. 857-860.

${ }^{45}$ Por. T. Wynn, A. Hernandez-Aguilar, L. Marchant, W. C. McGrew, An Ape's View of the Oldowan'Revisited, „Evolutionary Anthropology” 20 (2011), s. 181-197; G. B. Tostevin, Special Issue: Reduction Sequence, Chaîne Opératoire, and Other Methods - the Epistemologies of Different Approaches to Lithic Analysis. Levels of Theory and Social Practice in the Reduction Sequence and Chaîne Opératoire Methods of Lithic Analysis, „PaleoAnthropology” (2011), s. 351-375. 
narzędziotwórczej. Przeprowadzone analizy prowadzą do przeciwnych wniosków, ukazując poznawczą złożoność zabiegów technicznych pierwszych hominidów. Dzięki coraz liczniejszym badaniom i nowym wykopaliskom zmienia się obraz hominidów żyjących na przełomie plio-plejstocenu ${ }^{46}$. W literaturze przedmiotu analizującej działalność narzędziową naszych przodków wprost wskazuje się na pewne kognitywne implikacje, takie jak „dalekowzroczność”, „przewidywanie”, „planowanie” (foresight, anticipation, planning) ${ }^{47}$. Tak na temat zmiany w postrzeganiu behawioru plio-plejstoceńskich hominidów piszą Jorge Martínez-Moreno, Rafael Mora Torcal i Ignacio de la Torre:

Olduwajskie artefakty są rozpatrywane jako rezultat prostego procesu; ta koncepcja produktów wytworzonych w doraźny sposób, bez spełnienia jakiegoś kryterium organizacyjnego, rozpatruje łupanie jako zwykłe zastosowanie siły do otoczaków (...). Mierząc się z tą perspektywa, aktualne odkrycia z różnych miejsc w Afryce Wschodniej stawiają pod znakiem zapytania to ujęcie (...) można tam zaobserwować techniczne umiejętności, które są wyższe, niż zwykle się przypuszczało. To wskazywałoby, że te hominidy posiadały zdolności, które były daleko bardziej rozwinięte, niż dotychczas sugerowano. Inaczej mówiąc, ta diagnoza nie pasuje dobrze do określenia artefaktów jako wyprodukowanych w doraźny i rudymentarny sposób, jak to bywa tradycyjnie przedstawiane ${ }^{48}$.

${ }_{46}$ Zob. T. Plummer, Flaked Stones..., dz. cyt.; H. Roche, From Simple Flaking..., dz. cyt.; K. D. Schick, N. Toth, An Overview of the Oldowan..., dz. cyt.; E. Hovers, D. R. Braun, Interdisciplinary Approaches to the Oldowan, New York 2009; H. Roche, R. J. Blumenschine, J. S. Shea, Origins and Adaptations of Elary Homo: What Archaeology Tell Us, w: The First Humans: Origin and Early Evolution of the Genus Homo, ed. F. E. Grine, J. G. Fleagle, R. E. Leakey, Dordrecht 2009; S. Harmand et al., 3.3-million-year-old..., dz. cyt.

${ }_{47}$ Zob. A. Delagnes, H. Roche, Late Pliocene..., dz. cyt.; S. Harmand, Variability in Raw..., dz. cyt.

${ }^{48},[\mathrm{~T}]$ he Oldowan artefacts, they are considered as the result of a simple process; this notion of products created in an expeditive way, without fulfilling any organisational criteria, considering the knapping as the mere application of force on the cobbles (...). Faced with this perspective, recent discoveries made at various sites in Eastern Africa question this view (...) there exists a technical competence which is higher than is usually supposed. This would indicate that these hominids posses- 
Konsekwencją analiz opartych na materiale empirycznym pochodzącym ze stanowiska Lokalalei $2 \mathrm{C}$ jest dostrzeżenie zaawansowanych procesów poznawczych hominidów wytwarzających pierwsze narzędzia kamienne, co może stawiać pod znakiem zapytania tezy uwydatniające rolę przypadku w nabywaniu kompetencji technicznych pierwszych hominidów i jednocześnie wspierać tezy o pewnej stałej dyspozycji poznawczej charakterystycznej dla człowieka, a w swoim rudymentarnym zakresie widocznej już u naszych najstarszych praprzodków ${ }^{49}$. Na płaszczyźnie opisanych zabiegów technicznych, począwszy od okresu plio-plejstocenu aż do okresu holocenu, w procesie wytwarzania najprostszych narzędzi kamiennych zachodzą liczne podobieństwa. To, że pierwsze hominidy nie znały tajników rzemiosła znanych np. ze schyłku plejstocenu, w niczym nie umniejsza faktu, że to właśnie technika pierwszych hominidów (olduwajska) przetrwała ponad 2 mln lat, co może wspierać tezę o poznawczej ciagłości człowieka współczesnego i naszych przodków. Należy również nadmienić, że oprócz prób rekonstrukcji behawioru hominidów na podstawie znalezisk archeologicznych - podejmowane w ramach archeologii eksperymentalnej zabiegi wskazują na to, że współcześni adepci sztuki wytwarzania narzędzi kamiennych musza posiadać odpowiednie kompetencje poznawcze i manualne, które zasadniczo obejmują te same selektywne, skorelowane i zintegrowane zabiegi techniczne, które dostrzegamy u naszych antenatów. Odrzucenie tego typu prób interpretacji procesów poznawczych związanych z wytwarzaniem narzędzi kamiennych skazuje nas na regres w badaniach i pozostawanie w sferze niewyjaśnionej przypadkowości i losowości działań.

sed abilities which were far more developed than hitherto proposed. In other words, this diagnosis does not fit well with the notion of artifacts being made in an immediate and rudimentary manner, as has been defended traditionally" - J. Martínez-Moreno, R. Mora Torcal, I. de La Torre, Oldowan, rather more than Smashing Stones: An Introduction to "The Technology of First Humans" Workshop, w: Oldowan: Rather more than Smashing Stones, ed. J. Martínez-Moreno, R. Mora Torcal, I. de la Torre, Barcelona 2003, s. 15-16.

${ }_{49}$ Zob. A. Delagnes, H. Roche, Late Pliocene..., dz. cyt.; H. Roche, From Simple Flaking..., dz. cyt.; S. Harmand, Variability in Raw..., dz. cyt. 


\section{Summary}

\section{Attempts at modelling tool dynamics of first hominids in the light of cognitive archaeology}

The first traces the production of numerous stone tools from the period of the Plio-Pleistocene represent a deep antiquity technical processes in the context of human evolution. Determining cognitive ability needed to convey the first hominids manufacture of stone tools is a challenge for the cognitive archaeology. Currently, thanks to archaeological discoveries and the development of cognitive science we can try to restore all the necessary treatments aimed at the production and use of stone tools along with a broad understanding of their underlying cognitive processes. Analyses based on empirical data derived from Lokalalei - one of the oldest archaeological sites - indicate that the hominids comprehensive understanding of the principles of producing stone tools already at their very beginning.

Keywords: cognitive archaeology, hominids cognition, making and using stone tools, Lokalalei site

\section{Bibliografia}

Braun D., Rogers M., Harris J., Walker S., Landscape Scale Variation in Hominin Tool Use: Evidence from the Developed Oldowan, „Journal of Human Evolution" 55 (2008), s. 1053-1063.

Cognitive Archaeology and Human Evolution, ed. S. De Beaune, F. L. Coolidge, T. Wynn, Cambridge 2009.

Delagnes A., Roche H., Late Pliocene Hominid Knapping Skills: The Case of Lokalalei 2C, West Turkana, Kenya, „Journal of Human Evolution” 48 (2005), s. 435-472.

Geneste J. M., Analyse Lithique d'Industries Moustériennes du Périgord: Une Approche Technologique du Comportement des Groupes Humains au Paléolithique Moyen, Bordeaux 1985.

Goldman-Neuman T., Hovers E., Methodological Issues in the Study of Oldowan Raw Material Selectivity: Insights from A.L. 894 (Hadar, Ethiopia), w: Interdisciplinary Approaches to the Oldowan, ed. E. Hovers, D. R. Braun, Dordrecht 2009.

Gowlett J., Mental Abilities of Early Man: a Look at Some Hard Evidence, w: Hominid Evolution and Community Ecology, ed. R. Foley, London 1984. 
Harmand S., Economic Behaviors and Cognitive Capacities of Early Hominins between 2.34 Ma and 0.70 Ma in West Turkana, Kenya, „Mitteilungen der Gesellschaft für Urgeschichte" 16 (2007), s. 11-23.

Harmand S., Lewis J. E., Feibel C. S., Lepre C. J., Prat S., Lenoble A., Roche H. et al., 3.3-million-year-old Stone Tools from Lomekwi 3, West Turkana, Kenya, „Nature” 521 (2015), s. 310-315.

Harmand S., Raw Materials and Economic Behaviour of Late Pliocene Hominids: the Case of Lokalalei $2 C$ and Lokalalei 1 Sites, West Turkana (Kenya) (poster presented at the Paleoanthropology Society Annual Meeting, Montreal (Canada), March 30-31, 2004).

Harmand S., Variability in Raw Material Selectivity at the Late Pliocene Sites of Lokalalei, West Turkana, Kenya, w: Interdisciplinary Approaches to the Oldowan, ed. E. Hovers, D. R. Braun, Amsterdam 2009.

Hovers E., Braun D. R., Interdisciplinary Approaches to the Oldowan, New York 2009.

Human Evolution, Language and Mind: a Psychological and Archaeological Inquiry, ed. W. Noble, I. Davidson, Cambridge 1996.

Jones P. R., Experimental Butchery with Modem Stone Tools and Its Relevance for Paleolithic Archaeology, „World Archaeology” 12 (1980), s. 153-165.

Jones P. R., Results of Experimental Work in Relation to the Stone Industries of Olduvai Gorge, w: Excavations in Beds III, IV and the Masek Beds. Olduvai Gorge, vol. 5, ed. M. Leaky, D. Roe, Cambridge 1994.

Kibunjia M., Pliocene Archaeological Occurrences in the Lake Turkana Basin, „Journal of Human Evolution” 27 (1994), s. 159-171.

Kibunjia M., Roche H., Brown F. H., Leakey R. E., Pliocene and Pleistocene Archeological Sites West of Lake Turkana, Kenya, „Journal of Human Evolution" 23 (1992), s. 431-438.

Kozłowski J. K., Świat przed „rewolucja” neolityczna, Kraków 2004 (Wielka historia świata, 1).

Lenartowicz P., Zjawisko biologiczne a pojęcie racjonalności (spór o geneze pojęć teleologicznych), „Ruch Filozoficzny” 53 (1996) nr 2-3, s. 197-207.

Martínez-Moreno J., Mora Torcal R., de La Torre I., Oldowan, rather more than Smashing Stones: An Introduction to "The Technology of First Humans" Workshop, w: Oldowan: Rather more than Smashing Stones, ed. J. Martínez-Moreno, R. Mora Torcal, I. de la Torre, Barcelona 2003. 
McPherron S. P., Alemseged Z., Marean C. W., Wynn J. G., Reed D., Geraads D., Bobe R., Bearat H. A., Evidence for Stone-Tool-Assisted Consumption of Animal Tissues before 3.39 Million Years ago at Dikika, Ethiopia, „Nature" 466 (2010), s. 857-860.

McPherron S. P., Perspectives on Stone Tools and Cognition in the Early Paleolithic Record, w: Tool Use in Animals. Cognition and Ecology, ed. C. M. Sanz, J. Call, Ch. Boesch, Cambridge 2013.

Mithen S., The Prehistory of Mind, London 1996.

Pawlik A. F., Is the Functional Approach Helpful to Overcome the Typology Dilemma of Lithic Archaeology in Southeast Asia?, „IPPA Bulletin” 29 (2009), s. 6-14.

Pelegrin J., Remarks about Archaeological Techniques and Methods of Knapping: Elements of a Cognitive Approach to Stone Knapping, w: Stone Knapping, the Necessary Conditions for a Uniquely Hominin Behavior, ed. V. Roux, B. Bril, Cambridge 2005.

Plummer T. W., Bishop L. C., Ditchfield P., Hicks J., Research on Late Pliocene Oldowan Sites at Kanjera South, Kenya, „Journal of Human Evolution” 36 (1999), s. 151-170.

Plummer T., Flaked Stones and Old Bones: Biological and Cultural Evolution at the Dawn of Technology, ,Yearbook of Physical Anthropology” 47 (2004), s. $118-164$.

Renfrew C., Zubrow E. B. W., The Ancient Mind, Cambridge 1994.

Roche H., Blumenschine R. J., Shea J. S., Origins and Adaptations of Elary Homo: What Archaeology Tell Us, w: The First Humans: Origin and Early Evolution of the Genus Homo, F. E. Grine, J. G. Fleagle, R. E. Leakey, Dordrecht 2009.

Roche H., Delagnes A., Brugal J.-P., Feibel C., Kibunjia M., Mourre V., Texier P.-J., Early Hominid Stone Tool Production and Technical Skill 2.34 Myr ago in West Turkana, Kenya, „Nature” 399 (1999), s. 57-60.

Roche H., Delagnes A., Evidence of Controlled and Reasoned Stone Knapping at. 2.3 Myr, West Turkana (Kenya), Pont-Á-Mousson 2001 (International Workshop 21-24 November 2001, Abbaye des Prémontrés).

Roche H., From Simple Flaking to Shaping: Stone-knapping Evolution Among Early Hominids, w: Stone Knapping, the Necessary Conditions for a Uniquely Hominin Behavior, ed. V. Roux, B. Bril, Cambridge 2005. 
Roche H., Remarque sur les plus anciennes industries en Afrique et en Europe, w: Colloquium VIII: Lithic Industries, Language and Social Behaviour in the First Human Forms, Forli: IUPSS Congress, (1996), s. 55-68.

Roche H., Stone Knapping Evolution among Early Hominids, Pont-Á-Mousson 2001 (International Workshop, 21-24 November 2001, Abbaye des Prémontrés).

Roche H., Technological Evolution in Early Hominids, „OSSA: International Journal of Skeletal Research" 14 (1989), s. 97-98.

Schick K. D., Toth N., An Overview of the Oldowan Industrial Complex: The Sites and the Nature of Their Evidence, w: The Oldowan: Case Studies into the Earliest Stone Age, ed. N. Toth, K. Schick, Gosport 2006.

Schick K. D., Toth N., Making Silent Stones Speak: Human Evolution and the Dawn of Technology, New York 1993.

Semaw S., Renne P., Harris J. W. K., Feibel C. S., Bernor R. L., Fesseha N., Mowbray K., 2.5-million-year-old Stone Tools from Gona, Ethiopia, „Nature” 385 (1997), s. 333-336.

Semaw S., Rogers M. J., Quade J., Renne P. R., Butler R. F., Stout D., Dominguez-Rodrigo Hart W., Pickering T., Simpson S. W., 2.6-million-year-old Stone Tools and Associated Bones from OGS-6 and OGS-7, Gona, Afar, Ethiopia, „Journal of Human Evolution” 45 (2003), s. 169-177.

Semaw S., The Oldest Stone Artifacts from Gona (2.6-2.5 Ma), Afar, Ethiopia: Implications for Understanding the Earliest Stages of Stone Knapping, w: The Origins of Human Technology: Studies into the Early Stone Age (Oldowan), ed. N. Toth, K. Schick, Bloomington 2006.

Semaw S., The World's Oldest Stone Artifacts from Gona, Ethiopia: Their Implications for Understanding Stone Technology and Patterns of Human Evolution between 2.6-2.5 Million Years ago, „Journal of Archaeological Science" 27 (2000), s. 1197-1214.

Stone Tools and the Evolution of Human Cognition, ed. A. Nowell, I. Davidson, Boulder 2010.

Stout D., The Social and Cultural Context of Stone-Knapping Skill Acquisition, w: Stone Knapping: The Necessary Conditions for Uniquely Hominin Behaviour, ed. V. Roux, B. Bril, Cambridge 2005.

Tools, Language, and Cognition in Human Evolution, ed. K. Gibson, T. Ingold, Cambridge 1993. 
Tostevin G. B., Special Issue: Reduction Sequence, Chaîne Opératoire, and Other Methods - the Epistemologies of Different Approaches to Lithic Analysis. Levels of Theory and Social Practice in the Reduction Sequence and Chaîne Opératoire Methods of Lithic Analysis, „PaleoAnthropology” (2011), s. 351-375.

Toth N., Behavioral Inferences from Early Stone Artifact Assemblages: an Experimental Model, „Journal of Human Evolution” 16 (1987), s. 763-787.

Toth N., The Artefact Assemblages in the Light of Experimental Studies, w: Koobi Fora Research Project. Plio-Pleistocene Archaeology, ed. G. L. Isaac, Oxford 1997.

Toth N., The Oldowan Reassessed: a Close Look at Early Stone Artifacts, „Journal of Archaeological Science” 12 (1985), s. 101-120.

Toth N., The Stone Technologies of Early Hominids at Koobi Fora, Kenya: an Experimental Approach, Berkeley 1982.

Wynn T., Hernandez-Aguilar A., Marchant L., McGrew W. C., An Ape's View of the Oldowan' Revisited, „Evolutionary Anthropology” 20 (2011), s. 181197.

Wynn T., McGrew W. C., An Ape's View of the Oldowan, „Man” 24 (1989), s. 383-398.

Wynn T., The Intelligence of Later Acheulean Hominids, „Man” 14 (1979), s. 371-391.

Wynn T., The Intelligence of Oldowan Hominids, „Journal of Human Evolution” 10 (1981), s. 529-541. 